\title{
Some solutions for socio - economic development in the current period - a case study in Binh Phuoc province, Vietnam
}

\author{
Dinh Thi Huyen \\ Ly Tu Trong College, Ho Chi Minh City, Vietnam
}

\begin{abstract}
Summary: Once a province less developed than other localities across the country, but after more than 20 years of development, Binh Phuoc province has had a "makeover" in all aspects. A group of experts from Fulbright University Vietnam assessed that Binh Phuoc now has more obvious opportunities than ever before. If it knows how to make good use of it, Binh Phuoc can completely transform from the position of "development reserve" into a "development engine" of the Southeast region in particular as well as the whole country in general.
\end{abstract}

Keywords: Economy, society, Binh Phuoc, solutions, development.

\section{MAKE A PROBLEM}

$I^{n}$ 1997, Song Be province divided its administrative boundaries into two provinces of Binh Duong and Binh Phuoc. When it was newly established, Binh Phuoc was one of the poorest provinces of the country; the life of the people of ethnic groups in the province faces many difficulties. GDP per capita is only nearly 180 USD; the infrastructure is poor and outdated, and there is a serious shortage of officials in all branches of the province. The main economy of Binh Phuoc province is agro-forestry (accounting for more than 70\%), while industrial, commercial and service activities account for a very small part; Poor infrastructure, not synchronized. The rate of free migration is increasing, ethnic minorities account for about $20 \%$ with low educational attainment.

The 11th Congress of Binh Phuoc Provincial Party Committee, term 2020 - 2025 opened, with the theme "Enhancing the leadership role of the Party, promoting the revolutionary tradition and the strength of solidarity of the whole people; focus on economic development, take care of people's lives, and ensure solid national defense and security". Political report at the Congress for the term 2015 - 2020, Binh Phuoc implemented economic restructuring, brought into play the strengths of the province, including implementing 6 key economic programs and 12 key projects contribute to positive changes in social life.

In particular, Binh Phuoc's budget revenue is 2 times higher than the resolution set forth with an average revenue growth rate of 22\%/year. Resolution of the 10th Congress of Binh Phuoc Party Committee sets a target of budget revenue of VND 4,850 billion in 2020. In fact, it is expected that in 2020, Binh Phuoc's budget revenue will reach more than
10,000 billion VND. There are 13 industrial parks in the area with an area of more than 4,680 hectares; in which, 5 zones have been filled; the economy shifted in a positive direction, in which, industry - construction contributed $43 \%$ of the economy's value. Culture is closely linked in all activities of society, promoting traditional values, cultural and historical heritage; The movement "all people unite to build a cultural life" goes into depth and substance. The scale of education in the province has been expanded, the model and organization of the school apparatus has been streamlined. Besides, medical facilities and equipment were invested, in which Binh Phuoc General Hospital was upgraded from 300 to 600 beds; the quality of medical examination and treatment for the people is improved. The work of hunger eradication and poverty reduction is closely linked with the new rural construction program; the rate of poor households decreased to $1.56 \%$.

In the 2020 - 2025 term, Binh Phuoc province aims to become an industrial province by 2025 , in the group of fast and sustainable developing provinces, with a good economic scale in the key economic region of the Southeast region. Binh Phuoc focuses on improving people's quality of life, narrowing the gap between rural areas, ethnic minority areas, remote areas, border areas and urban areas in the province. The province strengthens regional connectivity; complete egovernment, smart city, gradually transition to digital government. At the same time, ensure solid defense-security; Party organization and a clean, strong and comprehensive political system.

\section{CONTENTS}

\subsection{Socio-economic situation in September and the first 9} months of 2021

On the basis of reviewing the implementation results of 8 months, the Binh Phuoc Department of Statistics estimated that in September, general results of the implementation of a number of key socio-economic indicators in the first 9 months of 2021 across sectors, Specific areas are as follows:

\subsubsection{Agriculture}

\section{a. Crop}


As of September 15, 2021, the agricultural production situation of the whole province is estimated to be implemented, specifically as follows: The cultivated rice area is 10,643 ha, down $5.61 \%$ (-633 ha) over the same period last year. (In which, the sowing season rice is 7,845 ha, down $4.64 \%$ over the same period). Corn was planted on 3,215 ha, up $0.53 \%(+17$ ha) over the same period; sweet potato planted 122 ha, down $74.64 \%$; 5,442 ha of cassava, down $8.07 \%$ over the same period. Sugarcane was planted on 188 hectares, down $1.57 \%$ ( -3 hectares), the province's sugarcane area was small, grown mainly as raw materials for beverage processing; Vegetables of all kinds planted 3,675 ha, down $1.13 \%$ (-42 ha) over the same period; Beans of all kinds were planted on 406 hectares, down $12.31 \%$ ( -57 hectares) over the same period. For perennial crops: it is estimated that the whole province currently has 431,864 ha of perennial plants, an increase of $0.48 \%(+2,076 \mathrm{ha})$ over the same period last year, of which: Fruit trees of all kinds 12,062 ha, down $2.27 \%$ (-280 ha) over the same period. The area of fruit trees decreased, the main reason was that some old trees with low yield and quality were replaced by other crops.

\section{b. Breed}

In general, livestock production is quite stable; The estimated number of cattle and poultry in the first nine months of 2021 includes: Buffalo: 13,531 heads, up $0.98 \%$ over the same period; the number of animals released from slaughter was 3,207, an increase of $10.00 \%$; slaughter output is estimated at 813 tons, up $1.00 \%$ over the same period; Cows: 39,163 heads, up $0.16 \%$ over the same period; the number of animals released from the slaughterhouse was 12,155, an increase of $1.00 \%$; slaughter output is estimated at 2,114 tons, up $1.00 \%$ over the same period; Pigs: 1,171,600 heads, up $9.33 \%$ over the same period; the number of animals released from slaughter was $1,018,212$, increasing by $1.00 \%$; slaughter output is estimated at 99,621 tons, up $10.00 \%$ over the same period; Poultry: 6,872 thousand heads, down $7.74 \%$ over the same period; sales volume reached 17,247 tons, down $2.00 \%$; sales of poultry eggs reached 124,693 thousand eggs, down $7.00 \%$ over the same period last year.

The epidemic situation in the total herd of cattle, poultry and other livestock in the first nine months of 2021 is quite stable with no major changes, no major epidemics have occurred. Animal quarantine is still carried out according to plan and is regularly checked and controlled, maintains animal quarantine points, completely handles outbreaks in communes when there is an epidemic in accordance with current regulations onion.

\subsubsection{Forestry}

In the first 9 months of 2021, especially the first months of the year, the weather in the province is sunny and hot on a large scale. The sector regularly directs affiliated units to inspect, urge and guide forest owners to strengthen patrolling, forest protection, forest fire prevention and fighting, and maintain a 24-hour standing mode throughout. dry season to strictly control people entering forest areas with high fire risk, minimizing fire sources; timely detection of fire.

Situation of violations in the field of forest management, forest protection and forest product management: In the first 9 months of 2021, the total number of violations in the field of forest management, forest protection and forest product management 46 cases (down 47 cases) compared to the same period in 2020). Number of cases handled in the period: 45 cases (44 cases were administratively handled and 01 criminal case was handled). Total revenue and payment to the state budget: 434.61 million VND.

\subsubsection{Seafood}

The situation of aquaculture in the province is still maintained stable, no disease occurs. The province's aquaculture area currently has 1,707 hectares, so far most of the aquaculture area has been seeded for farming. Actual fishery output from the beginning of the year to September reached 3,420 tons (aquaculture output 3,151 tons and fishing output 250 tons).

\subsubsection{Economic cooperation and association in agriculture; farm economics}

Economic cooperation, production linkage: the province currently has 165 cooperatives and 01 union of agricultural and forestry cooperatives still operating in the area (there are 8 newly established agricultural and forestry cooperatives) and 01 Union of Agricultural and Forestry Cooperatives registered to operate (with 04 member cooperatives).

Farm economy: According to rural survey results, mid-term agriculture in Binh Phuoc province has 487 farms, divided into: 9 farms in Dong Xoai city; Phuoc Long town 10 farms; Binh Long town 15 farms; Bu Gia Map district 18 farms; Loc Ninh district 44 farms; Bu Dop district 16 farms; Hon Quan district 104 farms; Dong Phu district 40 farms; Bu Dang district 103 farms; Chon Thanh district 90 farms; Phu Rieng district 38 farms.

\subsubsection{Industrial production}

The index of industrial production in September 2021 was estimated at $108.36 \%$ over the previous month and $106.19 \%$ over the same period last year, an increase of $8.36 \%$ over the previous month and an increase of $6.19 \%$ compared to the same period last year. In which: the mining industry increased $36.87 \%$ over the previous month, down $49.10 \%$ over the same period last year; respectively: processing and manufacturing industry increased by $8.60 \%$, increased by $6.75 \%$; the production and distribution of electricity, gas, hot water, steam and air conditioning increased by $1.26 \%$, up by $15.30 \%$; water supply, management and treatment of waste and wastewater increased by $6.69 \%$, down $12.01 \%$. 
Generally, in the first nine months of 2021, the industrial production index increased by $14.02 \%$ over the same period last year. In which, the processing industry maintained a high growth rate of $14.90 \%$; electricity production and distribution increased by $11.17 \%$; water supply and waste and wastewater treatment industry increased by $0.79 \%$; mining industry decreased by $19.84 \%$.

\subsection{Stabilize the macro-economy, control inflation}

\subsubsection{Banking and insurance activities}

Regarding interest rates: Deposit interest rates are at $0.1-0.2 \% / y e a r$ for demand deposits and term deposits of less than 1 month; 3.1-3.8\%/year for deposits with term from 1 month to less than 6 months; 4.0-5.9\%/year for term deposits from 6 months to less than 12 months; term from 12 months at 5.6-6.7\%/year. The maximum short-term lending interest rate for a number of priority sectors and fields is at: $4.5 \%$ year; of the people's credit fund is 5.5\%/year. The average lending interest rate for new and old loans with outstanding balances of popular credit institutions is at 8.5-10.5\%/year.

Total revenue as of August 31, 2021 is VND $2,113.22$ billion, reaching $61 \%$ of the plan, of which: Compulsory social insurance: VND 1,393.51 billion, reaching $62.6 \%$ of the plan; voluntary social insurance: 24.11 billion VND, reaching $50.1 \%$ of the plan; health insurance: 589.49 billion dong, reaching $57.5 \%$ of the plan; Unemployment insurance: 104.37 billion VND, reaching $62.9 \%$ of the plan.

Total expenditure as of August 31, 2021: 1,419.76 billion VND, including: Social insurance expenditure: 970.56 billion VND; health insurance spending: 338.58 billion VND; unemployment insurance expenditure: 110.62 billion dong.

\subsubsection{Investment and construction}

Realized social investment capital in the first 9 months of 2021 increased by $7.47 \%$ over the same period in 2020. In which, the private economic sector accounted for the largest proportion of total investment capital (60.26\%). However, investment capital of state-owned enterprises achieved the highest growth rate (up 45.09\%), this is the result of preferential policies, supporting and creating conditions for enterprises to expand production. business.

Generally for the first nine months of 2021, realized social investment capital at current prices was estimated at 16,394.32 billion VND, up 7.47\% over the same period last year, of which: State capital reached 3,399.92 billion dong, accounting for $20.74 \%$, up $24.16 \%$ over the same period last year; the non-state sector reached $9,878.68$ billion VND, accounting for $60.26 \%$, down $1.02 \%$; the foreign direct investment sector reached VND 3,088.22 billion, accounting for $18.84 \%$, up 22.67\%; Other deposits reached VND 27.48 billion, accounting for $0.16 \%$, up $41.43 \%$. Of the total investment capital of the State sector, capital from the State budget managed by localities in 9 months was estimated at $2,900.48$ billion VND, equaling $42.20 \%$ of the year plan, up
$13.10 \%$ compared to the year plan. with the same period last year, including: provincial state budget capital reached $2,185.54$ billion dong, equaling $41.08 \%$ of the year plan, up 26.19\%; State budget capital at district level reached 714.94 billion VND, equaling $46.02 \%$ and increasing by $85.88 \%$.

\subsection{Some solutions for socio-economic development in Binh Phuoc province today}

Firstly, direct the implementation of solutions to stabilize the market, connect supply and demand, especially essential commodities; promote the implementation of programs of activities to stimulate consumption demand. Strengthen trade promotion and e-commerce activities to consume and export products. Speed up the implementation of the plan to support businesses in digital transformation in the province.

Second, speed up the disbursement of public investment capital; implementing Resolution 105/NQ-CP dated September 9, 2021 of the Government on supporting businesses, cooperatives and business households in the context of the COVID-19 epidemic in the province.

Third, focus on supporting and creating favorable conditions for tourism businesses and transport enterprises to resume operations in the new situation. Strengthening information, promotion and image promotion of Binh Phuoc tourist destination; promulgate Regulations on management of tourist areas in the province; at the same time organize a variety of events and activities to stimulate demand to restore domestic tourism.

Fourthly, well implement plans and plans to ensure security and order at field hospitals, concentrated isolation areas, and checkpoints for COVID-19 disease prevention and control in the area; propagating and mobilizing people to strictly observe regulations on epidemic prevention and control.

Fifth, continue to direct and urge the rapid implementation of support payments for employees and employers facing difficulties due to the COVID-19 pandemic according to Resolution No. 68/NQ-CP, Resolution No. 126 /NQ-CP, Decision No. 23/2021/QD-TTg of the Government.

\section{CONCLUSION}

Despite facing many difficulties, businesses and business households in the province are gradually adapting to the new situation and have made adjustments in production and business plans to open more consumer markets goods at home and for export in order to restore production and business after damage caused by the Covid-19 epidemic. To achieve the above goals, districts, towns and cities must strengthen inspection, require businesses and business households, especially types of food and beverage services, to commit to strictly complying with regulations, epidemic prevention and control plan in production and business recovery. At the same time, it is required that departments, 
agencies and branches continue to have solutions to support businesses; accelerate the disbursement of public investment capital, stabilize the economy in the new situation, contributing to the stability and socio-economic development of Binh Phuoc province today./.

\section{REFERENCES}

[1] An Nhien (2021). Binh Phuoc province's socio-economy has many bright spots, https://dangcongsan.vn/ Kinh-te/ Kinh-te-xa-hoi-tinhbinh-phuoc-co-nhieu-diem -sang-594014.html

[2] Binh Phuoc Provincial Statistical Office (2021). Summarizing the results of some key socio-economic indicators in the first 9 months of 2021 across sectors and fields.

[3] Binh Phuoc Provincial Party Committee (2015). Resolution of the 10th Congress, internally circulated.

[4] Binh Phuoc Provincial Party Committee (2020). Resolution of the 11th Congress, internally circulated.

[5] Dinh Trong (2021). Binh Phuoc soon becomes a fast and sustainable industrial province, https://laodong.vn/ Kinh-te/binhphuoc-som-tro-thanh-tinh-cong-nghiep-phat -trien-fast-ben-vung877583.ldo

[6] Government of Vietnam (2021). Resolution 105/NQ-CP on supporting businesses, cooperatives and business households in the context of the COVID-19 epidemic.

[7] Mai Quoc Dung (2021). The communist party of Vietnam leads the work of international integration from 1986 to 2021, Review of International Geographical Education Online 11 (10), page. $1751-1758$

[8] Sy Tuyen (2020). Binh Phuoc - Strategic vision and aspiration to rise, https://binhphuoc.gov.vn/en/news/tin-noi-bat/binh-phuoctam-nhin-chien-luoc -va-khat-vong-vuon-len-23371.html

[9] Prime Minister of Vietnam (2021). Resolution No. 126/NQ-CP loosening conditions for receiving Covid support. 